\title{
Динаміка змін в антиоксидантно-прооксидантній системі в тканинах нирок при травмі органів черевної порожнини на фоні гіповолемічного шоку та синдрому ішемії-реперфузї
}

\begin{abstract}
Мета роботи: вивчити вплив реперфузії кінцівки в моделі поєднаної травми органів черевної порожнини та гіповолемічного шоку на зміни антиоксидантно-прооксидантних механізмів у тканинах нирки.

Матеріали і методи. В експерименті використали 80 статевозрілих білих щурів-самців лінії Wistar масою 190-220 г, які знаходилися на стандартному раціоні віварію.

Усіх тварин розділили на групи: контрольну і 3 дослідні (по 8 тварин у кожній групі). У тварин першої дослідної групи під тіопентало-натрієвим знеболенням $\left(40\right.$ мг $\left.\mathrm{k}^{-1}\right)$ проксимально на ліві лапки накладали кровоспинний джгут терміном на 120 хв. У другій дослідні групі було змодельовано поєднану травму органів черевної порожнини шляхом нанесення двох дозованих ударів у ділянку черевної порожнини; гіповолемічний шок моделювали шляхом кровопусканням від 20 до 22 \% об’єму циркулюючої крові з стегнових судин. В третій дослідній групі моделювали поєднану травму органів черевної порожнини та реперфузію кінцівок. Тварин контрольної групи вводили тільки в наркоз.

Тварин дослідних груп виводили з експерименту в умовах тіопентало-натрієвого наркозу методом тотального кровопускання з серця через 1, 3 та 7 діб після репрерфузії. Для дослідження забирали нирки тварин.

У гомогенатах нирки визначали активність каталази, вміст реагентів до тіобарбітурової кислоти (ТБК-активних продуктів) та на основі цих даних розраховували антиоксидантно-прооксидантний індекс.

Результати досліджень та їх обговорення. Встановлено, що реперфузія кінцівки спричиняє тривалий оксидативний стрес у тканинах нирки, про що свідчить значне накопичення ТБК-активних продуктів ПОЛ в її тканині. Виявлено однотипність у динаміці змін рівня ТБК-активних продуктів ПОЛ та активності каталази між групами тварин із реперфузійними змінами та групою, де моделювали закриту травму органів черевної порожнини та гіповолемічний шок.

У групі тварин, де поєднували реперфузію, травму органів черевної порожнини та гіповолемічний шок, розвивалося виснаження антиоксидантних механізмів, про що свідчила динаміка показника АПІ до сьомої доби, коли він на 37,8 \% був статистично менше контрольних показників ( $<0,05)$. Це свідчить про високий ризик розвитку синдрому поліорганної недостатності та необхідність подальшого вивчення та розробки засобів корекції та профілактики.
\end{abstract}

Ключові слова: ішемія; реперфузія; джгут; експеримент; нирка; перекисне окиснення ліпідів.

Постановка проблеми і аналіз останніх досліджень та публікацій. Згідно з даними Центру за контролем захворювань щороку понад 14 млн осіб із тавмами кінцівок відвідують відділення невідкладної медичної допомоги, приблизні економічні втрати внаслідок цього складають 80 млрд дол. США [1]. Тяжкі травми кінцівок є однією 3 найрозповсюдженіших травм як у цивільній медицині, так і під час військових дій $[2,3]$. Також відомо, що кровотеча при травмах кінцівок $є$ найпоширенішою причиною смертності, яку можна запобігти (превентивні смерті) як у цивільних умовах, так і в умовах бойових дій $[4,5]$.

Використання артеріального джгута як ефективного засобу для зупинки кровотечі широко використовується, особливо в останні роки [6]. Проведений аналіз встановив, що використання кровоспинних джгутів може бути причиною деяких ускладнень (некроз скелетних м'язів, функціональне ушкодження нервів), включно ішемічнореперфузійні пошкодження [7].

Окремі експериментальні досліди на тваринах показали, що накладання джгута на дві годи- ни призводили до значного зростання молочної кислоти, креатинфосфокінази, що свідчило про пошкодження м'язів. Більшість клінічних досліджень підтвердила, що безпечне використання накладання джгута допустимо не більш ніж на 6090 хв. 3 іншого боку, численні публікації вказують, що безпечним $є$ накладанням джгута на дві години. Однак слід зазначити, що ці рекомендації стосуються здебільшого випадків військової медицини або надзвичайних станів із значною кількість постраждалих [7-9]. Також більшість робіт в цьому напрямку стосується ізольованої травми кінцівок. Особливості впливу ішемії-реперфузії при поєднаній травмі не вивчено.

Зрозуміло, що у багатьох випадках надзвичайних ситуацій тривалий час використання джгутів необхідне для збереження життя. Тому дуже важливо є вивчити механізми, які виникають при ішемії-реперфузії, після накладання джгутів.

Основним механізмом пошкодження після ішемії-реперфузії є генерація активних форм кисню, які ініціюють пероксидне окиснення ліпідів (ПОЛ). Враховуючи недостатність системи анти- 
оксидантного захисту, спостерігається системне виражене пошкодження клітинних мембран внаслідок пероксидації їхнього ліпідного біошару. Вищевказані процеси повинні поглиблюватись на фоні додаткової ішемії, спричиненої поєднаною травмою та супутнім гіповолемічним шоком. Однак ці механізми потребують уточнення та додаткового вивчення.

Мета роботи: вивчити вплив реперфузії кінцівки в моделі поєднаної травми органів черевної порожнини та гіповолемічного шоку на зміни антиоксидантно-прооксидантних механізмів у тканинах нирки.

Матеріали і методи. Робочою гіпотезою експериментального дослідження є припущення, що використання кровоспинного джгута та подальша реперфузія ішемізованих тканин призводить до надмірного утворення активних форм кисню, гіперпродукції токсичних метаболітів, сигнальних молекул цитокінового ряду та інших медіаторів запалення, які здійснюють системний вплив на організм із порушенням життєдіяльності внутрішніх органів при поєднаній травмі органів черевної порожнини на фоні гіповолемічного шоку та може стати причиною розвитку поліорганної недостатності.

3 метою реалізації поставленої мети на 80 нелінійних щурах-самцях масою 190-220 г було виконано експериментальне дослідження. Усіх тварин розділили на групи: контрольну і 3 дослідні (по 8 тварин у кожній групі).

У тварин першої дослідної групи (ГД - 1) під тіопепнтало-натрієвим знеболенням (40 мг·кГ-1) проксимально на ліві лапки накладали кровоспинний джгут терміном на 120 хв. В якості джгута застосовували еластичну смужку джгута "SWAT-T" (США) завширшки 10 мм, що відповідає ширині джгута при накладанні на стегно дорослій людині. Джгут затягували відповідно до нанесеного на ньому індикатора ефективного тиску. Накладання кровоспинного джгута терміном на дві години накладали з метою моделювання ішемічно-реперфузійного синдрому.

У другій дослідні групі (ГД - 2) було змодельовано поєднану травму органів черевної порожнини: після проведення наркозу тіопенталом-натрію (40 мг·кГ-1), тварині наносили два дозовані удари в ділянку черевної порожнини за допомогою спеціального пристрою - сила нанесення удару розраховувалась таким чином, щоб не виникала внутрішня кровотеча; крововтрата досягалась шляхом виконання операційного доступу і пересікання стегнових судин в об’ємі від 20 до 22 \% об’єму циркулюючої крові тварини протягом однієї хвилини (гостра крововтрата), після чого кровотеча зупинялась шляхом перевязування судин.

У третій дослідній групі (ГД - 3) моделювали поєднану травму органів черевної порожнини та ішемічно-реперфузійний синдром відповідно до методик описаних вище.

Тварин дослідних груп виводили з експерименту в умовах тіопентало-натрієвого наркозу (60 мг·кг $\Gamma^{-1}$ ) методом тотального кровопускання 3 серця через 1, 3 та 7 діб після репрерфузії. Для дослідженняя забирали нирки тварин. В контрольній групі (КГ) тварин тільки вводили в наркоз, застосовуючи еквівалентну дозу тіопенталу-натрію, і в подальшому виводили з експерименту через 2 год. Отримані дані порівнювали з КГ.

У гомогенатах нирки визначали активність каталази - ключового компонента ферментативної ланки антиоксидантного захисту [10, 11] та вміст реагентів до тіобарбітурової кислоти (ТБКактивних продуктів), які належать до індикаторних показників інтенсивності пероксидного окиснення ліпідів (ПОЛ) [12]. На основі цих даних розраховували антиоксидантно-прооксидантний індекс (АПІ = активність каталази / вміст ТБКактивних продуктів ПОЛ). Він належить до чутливих індикаторів стану антиоксидантного захисту та відображає баланс між антиоксидантними і прооксидантними механізмами.

Дослідження зазначених показників визначали в Центральній науковій лабораторії Тернопільського державного медичного університету імені I. Я. Горбачевського.

Вірогідність відмінностей між контрольною і дослідними групами оцінювали з використанням непараметричного критерію Манна-Уїтні. Відмінності вважали істинними при вірогідності нульової гіпотези менше 5 \% (p<0,05).

Результати досліджень та їх обговорення. Як показали наші дослідження, рівень ТБК-активних продуктів ПОЛ наростав у всіх дослідних групах (табл. 1, рис. 1). Так, в ГД - 1 рівень ТБК-активних продуктів ПОЛ через 1 добу після реперфузії перевищував контрольні на 100 \%, через 3 доби дещо зменшувався, однак перевищував контрольні на 86,8 \% та через 7 діб досягав максимальних значень, що було на 157,8 \% вище контрольних ( $<0,001)$. У ГД - 2 спостерігалось односпрямоване збільшення показника протягом всього часу спостереження, перевищення контрольних значень було на 248,7 \% через одну добу, на 302,6 \% на третю та 314,5 \% на сьому добу спостереження (p<0,001). Найвищі значення ТБК-активних про- 
Таблиця 1. Вміст ТБК-активних продуктів пОЛ у тканині нирки (мкмоль/кг¹) у динаміці реперфузії, Me (LQ;UQ) - медіана (нижній і верхній квартилі)

\begin{tabular}{|c|c|c|c|c|}
\hline \multirow{2}{*}{$\begin{array}{c}\text { Групи } \\
\text { дослідження }\end{array}$} & \multirow{2}{*}{ Контроль } & \multicolumn{3}{|c|}{ Термін дослідження } \\
\hline & & 1 доба & 3 доба & 7 доба \\
\hline ГД - 1 & \multirow[t]{3}{*}{$\begin{array}{c}0,72 \\
(0,66 ; 0,90)(n=8)\end{array}$} & $\begin{array}{c}1,47^{* * *}(1,35 ; 1,57) \\
(n=8)\end{array}$ & $\begin{array}{c}1,43^{* * *} \\
(1,33 ; 1,49)(n=8)\end{array}$ & $\begin{array}{c}1,93^{* * *}(1,91 ; 2,15) \\
(\mathrm{n}=8)\end{array}$ \\
\hline ГД - 2 & & $\begin{array}{c}2,55^{* * * *} \\
(2,43 ; 3,10)(n=8)\end{array}$ & $\begin{array}{c}2,96^{* * *} \\
(2,73 ; 3,52)(n=8)\end{array}$ & $\begin{array}{c}3,14^{* * *} \\
(3,11 ; 3,22)^{*}(n=8)\end{array}$ \\
\hline ГД - 3 & & $\begin{array}{c}3,31^{* * *} \\
(3,27 ; 3,57)(n=8)\end{array}$ & $\begin{array}{c}5,42^{* * *} \\
(5,21 ; 5,91)(n=8)\end{array}$ & $\begin{array}{c}6,50^{* * *} \\
(6,28 ; 6,98)(n=8)\end{array}$ \\
\hline \multicolumn{2}{|c|}{$\mathrm{p}_{1-2}$} & $<0,001$ & $<0,001$ & $<0,001$ \\
\hline \multicolumn{2}{|c|}{$\mathrm{p}_{1-3}$} & $<0,001$ & $<0,001$ & $<0,001$ \\
\hline \multicolumn{2}{|c|}{$\mathrm{P}_{2-3}$} & $<0,001$ & $<0,001$ & $<0,001$ \\
\hline
\end{tabular}

Примітки. Тут і в інших таблицях:

1. *** - відмінності стосовно контрольної групи статистично вірогідні $(\mathrm{p}<0,001)$;

2. $\mathrm{p}_{1-2}$ - вірогідність відмінностей між першою та другою дослідними групами;

3. $\mathrm{p}_{1-3}$ - вірогідність відмінностей між першою та третьою дослідними групами;

4. $\mathrm{p}_{2-3}$ - вірогідність відмінностей між другою та третьою дослідними групами.

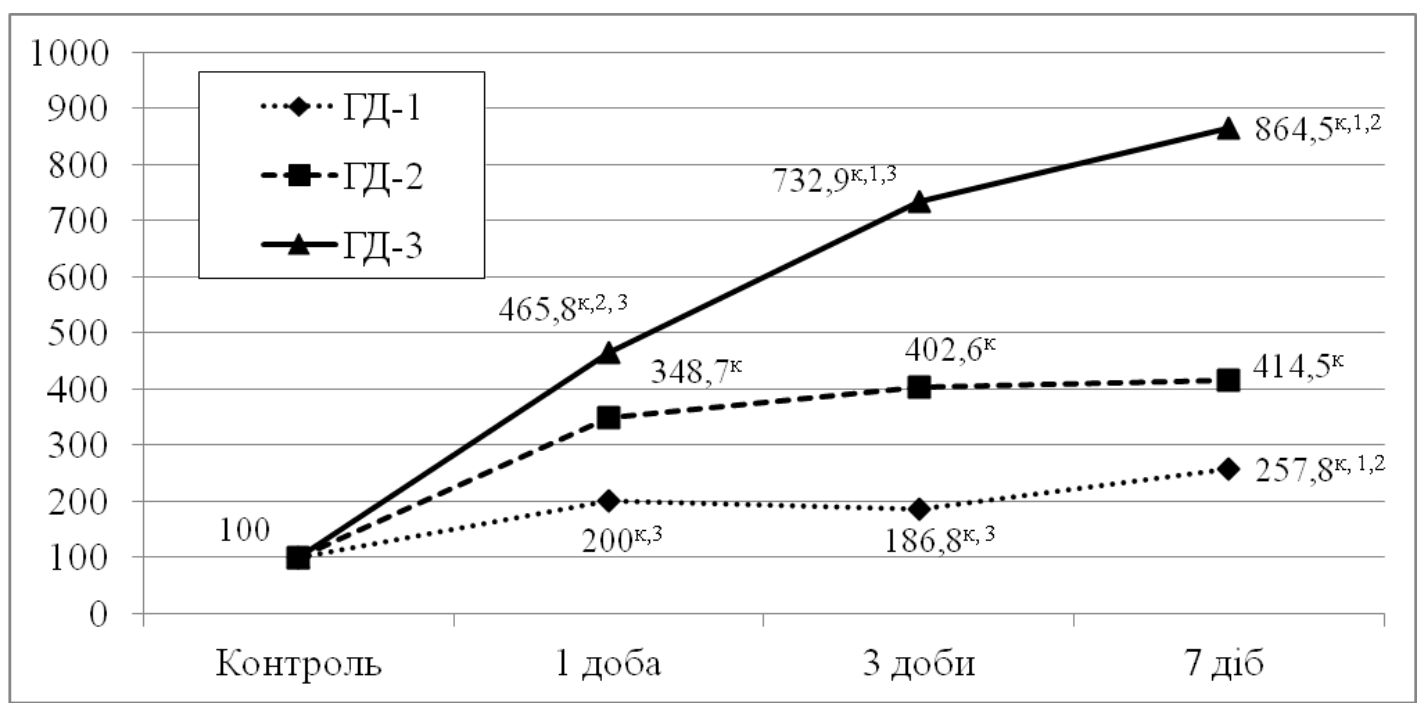

Рис. 1. Динаміка вмісту ТБК-активних продуктів ПОЛ у тканинах нирок (у відсотках від рівня контролю). Тут і на інших рисунках: к - відмінності стосовно контрольних показників (p<0,05); ${ }^{1,2,3}$ - відмінності відповідно $з$ показниками 1, 2 і 3 доби статистично вірогідні $(\mathrm{p}<0,05)$.

дуктів ПОЛ було визначено в ГД - 3, відповідно, на 365,8 \%, 632,9 \% та 764,5\% (p<0,001) більше ніж у КГ. Також у всіх контрольних точках спостереження між групами дослідження спостерігалась достовірна різниця ( $<<0,001)$.

В свою чергу, на фоні наростання ТБКактивних продуктів ПОЛ, в тканині нирок також спостерігалось збільшення рівня каталази в групах дослідження (табл. 2, рис. 2). Так, в ГД - 1 рівень каталази наростав до 3 доби спостереження, достовірно перевищував при цьому контрольні значення в 7,4 раза ( $<<0,001)$, до сьомої доби дещо зменшувався порівняно з попереднім, та був у 9,8 раза вище контрольних $(\mathrm{p}<0,001)$. У ГД - 2 як і в ГД - 1 спостерігалась аналогічна тенденція наростання до 3 доби спостереження та зниження до 7 доби спостереження. Показник каталази достовірно перевищував контрольні показники через сім діб у 9,8 раза $(\mathrm{p}<0,001)$. Як показав аналіз, на відміну від інших груп спостереження у ГД 3 показник каталази односпрямовано зменшувався протягом часу спостереження: через одну добу досягав максимальних значень в порівнянні 3 іншими групами досліджень та достовірно перевущував контрольні у 13,6 раза ( $<<0,001)$, через 3 доби різко зменшувався відносно попередніх показників та був достовірно вищим від контрольних у 9,3 раза $(\mathrm{p}<0,001)$, через 7 діб показник мав 


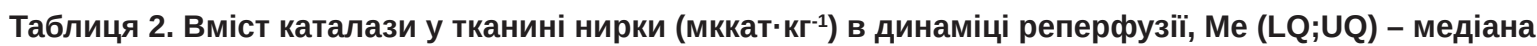
(нижній і верхній квартилі)

\begin{tabular}{|c|c|c|c|c|}
\hline \multirow{2}{*}{$\begin{array}{c}\text { Групи } \\
\text { дослідження }\end{array}$} & \multirow{2}{*}{ Контроль } & \multicolumn{3}{|c|}{ Термін дослідження } \\
\hline & & 1 доба & 3 доба & 7 доба \\
\hline ГД - 1 & \multirow[t]{3}{*}{$\begin{array}{c}1,33 \\
(1,12 ; 1,51)(n=8)\end{array}$} & $\begin{array}{c}9,25^{* * *}(9,00 ; 10,08) \\
(n=8)\end{array}$ & $\begin{array}{c}10,06^{* * *} \\
(9,68 ; 10,25)(n=8)\end{array}$ & $\begin{array}{c}9,40^{* * *}(9,22 ; 9,59) \\
(n=8)\end{array}$ \\
\hline ГД - 2 & & $\begin{array}{c}14,30^{* * *} \\
(12,55 ; 15,13)(n=8)\end{array}$ & $\begin{array}{c}16,62^{* * *} \\
(15,71 ; 17,98)(n=8)\end{array}$ & $\begin{array}{c}13,24^{* * *} \\
(12,70 ; 13,84)^{*}(n=8)\end{array}$ \\
\hline ГД - 3 & & $\begin{array}{c}19,06^{* * *} \\
(17,27 ; 19,51)(n=8)\end{array}$ & $\begin{array}{c}12,01^{* * *} \\
(11,37 ; 13,76)(n=8)\end{array}$ & $\begin{array}{c}7,55^{* * *} \\
(6,77 ; 8,17)(n=8)\end{array}$ \\
\hline \multicolumn{2}{|c|}{$\mathrm{p}_{1-2}$} & $<0,001$ & $<0,001$ & $<0,001$ \\
\hline \multicolumn{2}{|c|}{$\mathrm{p}_{1-3}$} & $<0,001$ & $<0,01$ & $<0,01$ \\
\hline \multicolumn{2}{|c|}{$\mathrm{p}_{2-3}$} & $<0,001$ & $<0,01$ & $<0,001$ \\
\hline
\end{tabular}

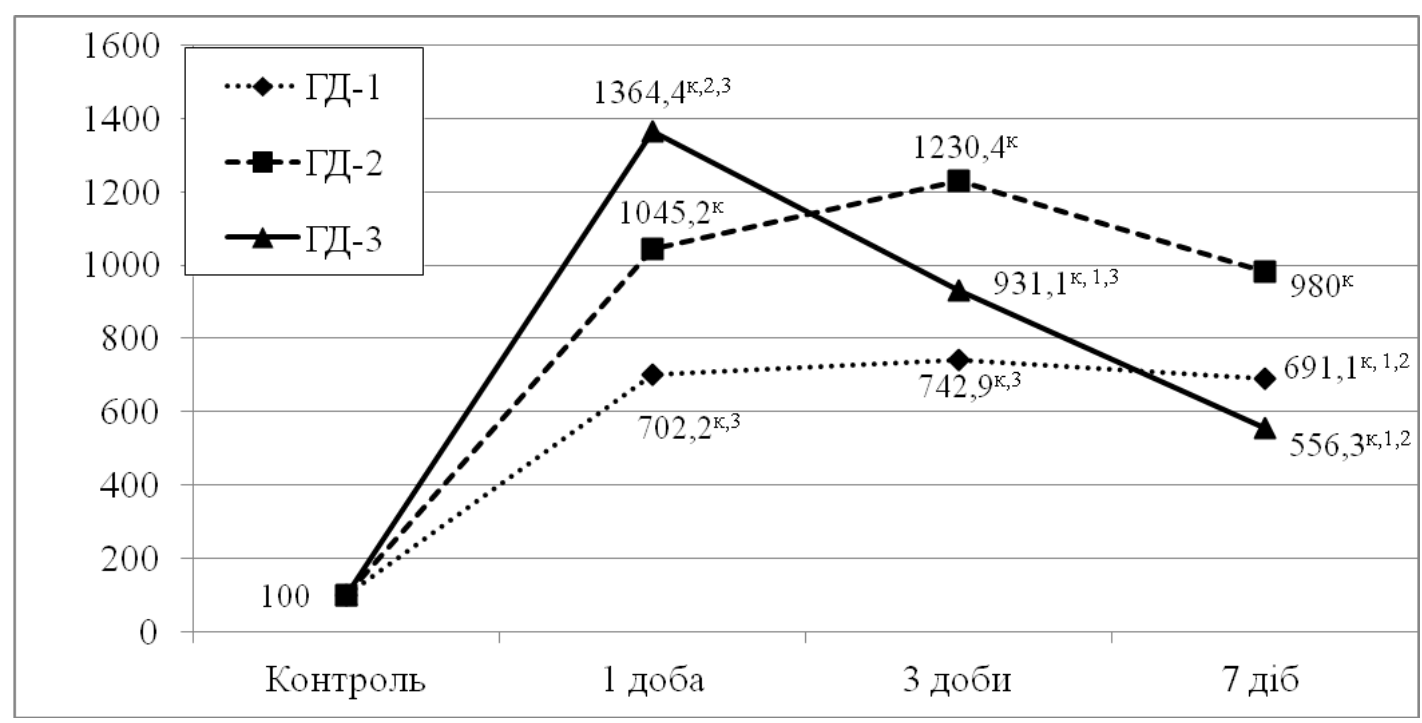

Рис. 2. Динаміка вмісту каталази у тканинах нирок (у відсотках від рівня контролю). Тут і на інших рисунках: к - відмінності стосовно контрольних показників ( $<0,05) ;{ }^{1,2,3}$ - відмінності відповідно з показниками 1,2 і 3 доби статистично вірогідні $(\mathrm{p}<0,05)$.

найнижчий рівень серед дослідних груп при цьому перевищував контрольні у 5,6 раза (р<0,001).

Наведена вище динаміка вмісту ТБК-активних продуктів ПОЛ і активності каталази не могла не позначитися на величині АПІ (табл. 3, рис. 3). Так, в ГД - 1 рівень АПІ був через одну добу у 3,4 раза, через три доби у 3,8 раза та через сім діб у 2,6 раза статистично більше $(\mathrm{p}<0,001)$ порівняно з показником КГ. У ГД - 2 у відповідно у 3,2 раза $(\mathrm{p}<0,01)$, у 3,0 раза та у 2,1 раза $(\mathrm{p}<0,001)$ вірогідно вище контролю.

На відміну від ГД - 1 та ГД - 2 рівень АПІ в ГД - 3 зменшувався до сьомої доби спостереження: через одну добу він був на 185,4 \% статистично більше $(p<0,001)$ контрольних показників, через три доби його рівень різко зменшувався відносно попередніх та перевищував контрольні лише на 23,2 \% (p<0,05), через сім діб він вже на 37,8 \% був статистично менше контрольних показників $(\mathrm{p}<0,05)$.

Слід зауважити що величина АПІ, яка відображає баланс прооксидантних і антиоксидантних механізмів, до 7 доби не нормалізувалася в ГД - 1. Це підтверджує наше припущення, що накладання кровоспинного джгута, навіть протягом безпечного періоду, викликає тривалі системні зміни в організмі та викликає тривале в часі напруження адаптаційно-компенсаторних механізмів, спрямованих на усунення патогенних чинників. Також, як показали результати дослідження, поєднання закритої травми органів черевної порожнини з геморагічний шоком та реперфузією кінцівки призводить до виникнення, з одного боку, тривалого оксидативного стресу, а зниження рівня АПІ до виснаження антиоксидантних механізмів. Відомо, що інтенсифікація процесів ПОЛ є одним із пус- 
Таблиця 3. Вплив реперфузії кінцівки на величину АПІ (ум. од.) у тканині нирки, Me (LQ;UQ) - медіана (нижній і верхній квартилі)

\begin{tabular}{|c|c|c|c|c|}
\hline \multirow{2}{*}{$\begin{array}{c}\text { Групи } \\
\text { дослідження }\end{array}$} & \multirow{2}{*}{ Контроль } & \multicolumn{3}{|c|}{ Термін дослідження } \\
\hline & & 1 доба & З доба & 7 доба \\
\hline ГД - 1 & \multirow[t]{3}{*}{$\begin{array}{c}1,58 \\
(1,43 ; 2,15)(n=8)\end{array}$} & $\begin{array}{c}6,28^{* * *}(5,76 ; 7,02) \\
(n=8)\end{array}$ & $\begin{array}{c}7,31^{* * * *} \\
(6,60 ; 7,48)(n=8)\end{array}$ & $\begin{array}{c}4,75^{* * *}(4,40 ; 5,08) \\
(n=8)\end{array}$ \\
\hline ГД - 2 & & $\begin{array}{c}5,05^{* *} \\
(4,76 ; 5,35)(n=8)\end{array}$ & $\begin{array}{c}5,45^{* * *} \\
(5,00 ; 6,07)(n=8)\end{array}$ & $\begin{array}{c}4,25^{* * *} \\
(4,08 ; 4,38)^{*}(n=8)\end{array}$ \\
\hline ГД - 3 & & $\begin{array}{c}5,47^{* * *} \\
(4,80 ; 5,86)(n=8)\end{array}$ & $\begin{array}{c}2,23^{*} \\
(2,05 ; 2,48)(n=8)\end{array}$ & $\begin{array}{c}1,17^{* *} \\
(0,95 ; 1,31)(n=8)\end{array}$ \\
\hline \multicolumn{2}{|c|}{$\mathrm{p}_{1-2}$} & $>0,05$ & $<0,05$ & $<0,05$ \\
\hline \multicolumn{2}{|c|}{$\mathrm{P}_{1-3}$} & $<0,05$ & $<0,001$ & $<0,001$ \\
\hline \multicolumn{2}{|c|}{$\mathrm{p}_{2-3}$} & $>0,05$ & $<0,001$ & $<0,001$ \\
\hline
\end{tabular}

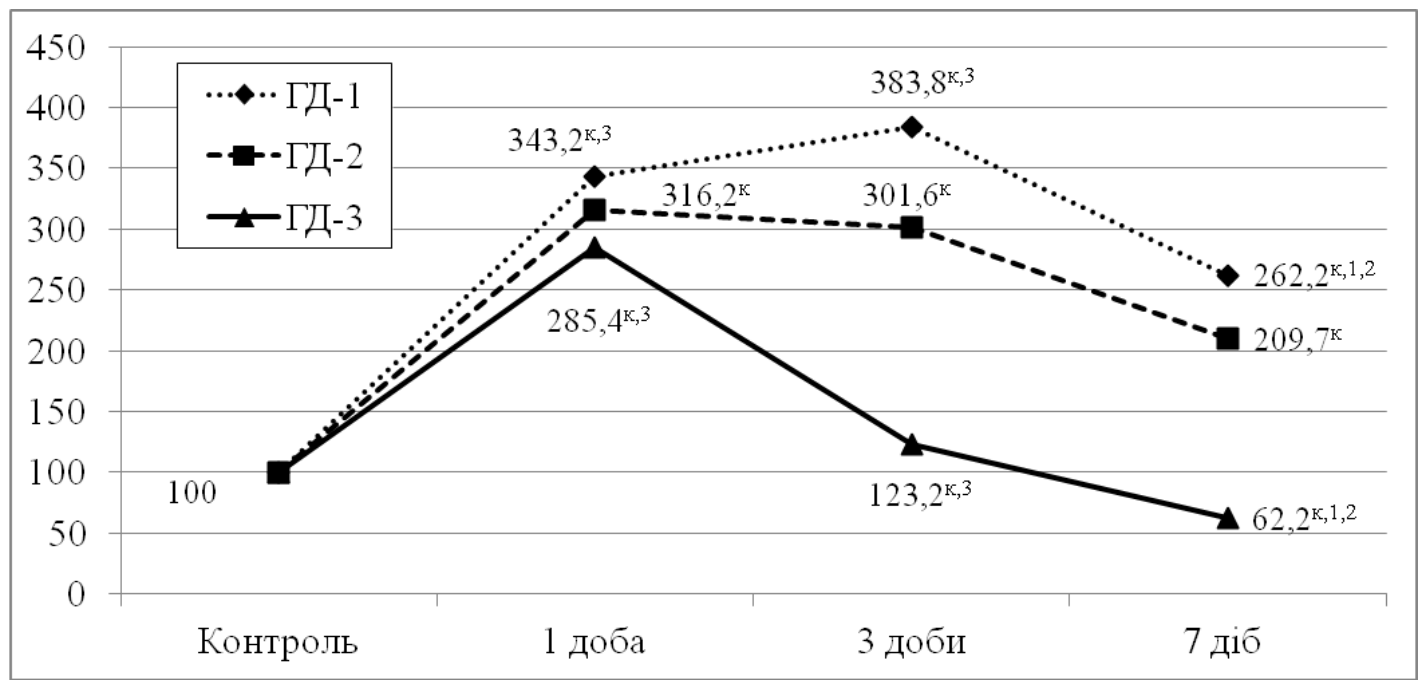

Рис. 3. Динаміка вмісту АПІ у тканинах нирок (у відсотках від рівня контролю). Тут і на інших рисунках: к відмінності стосовно контрольних показників (р<0,05); ${ }^{1,2,3}$ - відмінності відповідно з показниками 1,2 і 3 доби статистично вірогідні $(\mathrm{p}<0,05)$.

кових механізмів системної відповіді організму на запалення, яка, у свою чергу, значно збільшує ймовірність розвитку поліорганної недостатності.

Висновки. 1. Реперфузія кінцівки після двогодинного артеріального джгута супроводжується тривалою активацією процесів ліпідної пероксидації, що проявляється статистично вірогідним $(\mathrm{p}<0,001)$ зростанням вмісту ТБК-активних продуктів ПОЛ в ГД - 1, з максимумом через 7 діб.

\section{СПИСОК ЛІТЕРАТУРИ}

1. Center for Disease Control Prevention. Estimated Number of Extremities Visited to Ed and Cost of Injury Reports. 2017. Available online at: https://wisqars.cdc.gov:8443/cost.

2. Mabry R. L. Tourniquet use on the battlefield / R. L. Mabry // Mil. Med. - 2006. -No. 171. - P. 352-356.

3. Tourniquet use for civilian extremity trauma / K. Inaba, S. Siboni, S. Resnick [et al.] // J. Trauma Acute Care Surg. -
2. Порушення балансу антиоксидантно-прооксидантних процесів був найбільш значимим у ГД - 3, де реперфузія кінцівки поєднувалась з закритою травмою органів черевної порожнини та гіповолемічним шоком.

Перспективи подальших досліджень. У перспективі передбачається розробити патогенетично обгрунтовані засоби корекції системних змін, що виникать під впливом реперфузії кінцівки. 
Huiyin, Zhang Dongze // Hindlimb Front Physiol. - 2018. No. 9. - P. 244.

6. Causes of death in U.S. Special Operations Forces in the global war on terrorism: 2001-2004 / J. B. Holcomb, N. R. McMullin, L. Pearse [et al.] // Ann. Surg. - 2007. - No. 245. - P. 986-991.

7. New Effective Tourniquets for Potential Use in the Military Environment: A Serving Soldier Study / Alastair Beaven, Rob Briard, Mark Ballard, Paul Parker // Military Medicine. - 2017. - Vol. 182 (7). - P. 1929-1932.

8. Epidemiology of mass casualty incidents in the United States / E. Schenk, G. Wijetunge, N. Mann [et al.] // Prehospital Emergency Care. - 2014 - Vol. 18 (3). - P. 408-416.

9. King D. R. Tourniquet use at the Boston Marathon bombing: Lost in translation / D. R. King, A. Larentzakis, E. P. Ramly //

\section{REFERENCES}

1. Center for Disease Control Prevention (2017). Estimated Number of Extremities Visited to Ed and Cost of Injury Reports. Retrieved from: https://wisqars.cdc.gov:8443/cost.

2. Mabry, R.L. (2006). Tourniquet use on the battlefield. Mil. Med. 171, 352-356.

3. Inaba, K., Siboni, S., Resnick, S., Zhu, J., Wong, M.D., Haltmeier, T. (2015). Tourniquet use for civilian extremity trauma. J. Trauma Acute Care Surg., 79, 232-237.

4. Ode, G., Studnek, J., Seymour, R., Bosse, M.J., Hsu, J.R. (2015). Emergency tourniquets for civilians: can military lessons in extremity hemorrhage be translated? J. Trauma Acute Care Surg., 79, 586-591

5. Ryan, M. Corrick, Huiyin, Tu, Dongze Zhang, Aaron, N Barksdale, Robert, L. Muelleman, Michael, C. Wadman, \& YuLong, Li (2018). Dexamethasone protects against tourniquet-induced acute ischemia-reperfusion injury in mouse. Hindlimb Front Physiol., 9, 244.

6. Holcomb, J.B., McMullin, N.R., Pearse L., Caruso J., Wade C. E., Oetjen-Gerdes L., Champion H. R., et al. (2007). Causes of death in U.S. Special Operations Forces in the global war on terrorism: 2001-2004. Ann. Surg., 245, 986-991.

7. Alastair Beaven, Rob Briard, Mark Ballard, Paul Parker (2017). Two new effective tourniquets for potential use in the
Journal of Trauma and Acute Care Surgery. - 2015. - Vol. 78 (3). - P. 594-599.

10. Нагорная Н. В. Оксидативный стресс: влияние на организм человека, методы оценки / Н. В. Нагорная, Н. А. Четверик // Здоров’я дитини. - 2010. № 2. - [режим доступу]. http://www.mif-ua.com/archive/article/12762

11. Метод определения активности каталазы / М. А. Королюк, Л. И. Иванова, И. Г. Майорова, В. Е. Токарев // Лабораторное дело. - 1988. - № 1. - С. 16-19.

12. A review of recent studies on malondialdehyde as toxic molecule and biological marker of oxidative stress / D. Del Rio, A. J. Stewart, N. Pellegrini [et al.] // Nutr. Metab. Cardiovasc. Dis. - 2005. - Vol. 15. - P. 316-328. military environment: A serving soldier study. Military Medicine, 182 (7), 1929-1932.

8. Schenk, E., Wijetunge, G., Mann, N.C., Lerner, E.B., Longthorne, A., \& Dawson, D. (2014). Epidemiology of mass casualty incidents in the United States. Prehospital Emergency Care, 18 (3), 408-416.

9. King, D.R., Larentzakis, A., \& Ramly, E.P. (2015). Tourniquet use at the Boston Marathon bombing: Lost in translation. Journal of Trauma and Acute Care Surgery, 78 (3), 594-599. 10. Nagornaya, N.V., \& Chetveryk, N.A. (2010). Oksidativnyy stress: vliyanie na organism cheloveka, metody otsenki [Oxidative stress: effects on the human body, methods of evaluation]. Zdorovia dytyny - Child's Health, 2. - Retrieved from: http:// www.mif-ua.com/archive/article/12762 [in Russian].

11. Korolyuk, M.A., Ivanova, L.I., Mayorova, I.G., \& Tokarev, V.E. (1988). Metod opredeleniya aktivnosti katalazy [Method for determination of catalase activity]. Laboratornoe delo - Laboratory Work, 1, 16-19 [in Russian].

12. Del Rio, D., Stewart, A.J., \& Pellegrini, N. (2005). A review of recent studies on malondialdehyde as toxic molecule and biological marker of oxidative stress. Nutr. Metab. Cardiovasc. Dis., 15, 316-328.

Отримано 31.01.2018

Електронна адреса для листування: galunadoc@gmail.com

\author{
G. Y. TSYMBALIUK
}

I. Horbachevsky Ternopil State Medical University

\title{
DYNAMICS OF CHANGES IN ANTIOXIDANT-PROOXIDANT SYSTEM IN KIDNEY TISSUES AFTER TRAUMA OF ABBDOMINAL CAVITY WITH HYPOVOLEMIC SHOCK AND ISCHEMIA-REPERFUSION SYNDROME
}

The aim of the work: to study the effect of reperfusion of the limb in the model of combined injuries of the abdominal cavity and hypovolemic shock on changes in antioxidant-prooxidant mechanisms in the renal tissues.

Materials and Methods. In the experiment, 80 sexually mature white male rats, Wistar weighing 190-220 g, were found on a standard vivarium diet.

All animals were divided into groups: control and 3 experimental (8 animals in each group). In animals of the first experimental group under thiopental narcosis (40 mg • kg-1) proximal to the left paws was applied a hemostatic tourniquet for 120 minutes. In the second experimental group, a combined injury to the abdominal cavity was simulated by applying two dose hits to the abdominal region; hypovolemic shock was modeled by bloodletting from 20 to $22 \%$ of the volume of circulating blood from the femoral vessels. In the third experimental group, a combined injury of organs of abdominal cavity and reperfusion of extremities was simulated. 
Animals of experimental groups were withdrawn from the experiment under conditions of thiopental anesthesia by the method of total blood-flow from the heart after 1, 3 and 7 days after the reperfusion. Kidneys of animals were taken for the study.

The activity of catalase, the content of reagents for thiobarbituric acid (TBA-active products) was determined in kidney homogenates, and the antioxidant-prooxidant index was calculated on the basis of these data.

Results and Discussion. It was found that reperfusion of the limb causes prolonged oxidative stress in the tissues of the kidney, as evidenced by the significant accumulation of TBA-active products in its tissue. The same identity was determined in the dynamics of changes in the level of TBA-active products and catalase activity between animal groups with reperfusion changes and a group where simulated closed trauma of the abdominal cavity organs and hypovolemic shock.

In the group of animals where reperfusion was combined, trauma to the abdominal cavity and hypovolemic shock developed the depletion of antioxidant mechanisms, as evidenced by the dynamics of the API until the seventh day, when it was statistically lower than control values $(\mathrm{p}<0.05)$ at $37.8 \%$. This indicates a high risk of multiple organ failure syndrome and the need for further study and development of correction and prophylaxis.

Key words: ischemia; reperfusion; tourniquet; experiment; kidney; peroxide oxidation of lipids.

\section{Г. Ю. ЦЫМБАЛЮК}

ГВУз “Тернопольский государственный медицинский университет имени И. Я. Горбачевского МЗ Украины”

\section{ДИНАМИКА ИЗМЕНЕНИЙ В АНТИОКСИДАНТНО-ПРООКСИДАНТНОЙ СИСТЕМЕ В ТКАНИ ПОЧЕК ПРИ ТРАВМАХ ОРГАНОВ БРЮННОЙ ПОЛОСТИ НА ФОНЕ ГИПОВОЛЕМИЧЕСКОГО ІІОКА И СИНДРОМЕ ИНЕМИИ-РЕПЕРФУЗИИ}

Цель работы: изучить влияние реперфузии конечности в модели сочетанной травмы органов брюшной полости и гиповолемического шока на изменения антиоксидантно-прооксидантных механизмов в тканях почки.

Материалы и методы. В эксперименте использовали 80 половозрелых белых крыс-самцов линии Wistar массой 190-220 г, которые находились на стандартном рационе вивария.

Всех животных разделили на группы: контрольную и 3 исследовательских (по 8 животных в каждой группе). У животных первой группы под тиопентало-натриевым наркозом $\left(40\right.$ мг $\left.\bullet \mathrm{k}^{-1}\right)$ проксимально на левые лапки накладывали кровоостанавливающий жгут сроком на 120 мин. Во второй группе была смоделирована сочетанная травма органов брюшной полости путем нанесения двух дозированных ударов в область брюшной полости; гиповолемический шок моделировался путем кровопускания от 20 до 22 \% объема циркулирующей крови с бедренных сосудов. В третьей опытной группе моделировали сочетанную травму органов брюшной полости и реперфузию конечностей. Животных контрольной группы вводили только в наркоз.

Животных опытных групп выводили из эксперимента в условиях тиопентал-натриевого наркоза методом тотального кровопускания из сердца через 1, 3 и 7 суток после репрерфузии. Для исследования забирали почки животных.

В гомогенатах почки определяли активность каталазы, содержание реагентов в тиобарбитуровой кислоте (ТБК-активных продуктов), и на основании этих данных рассчитывали антиоксидантными-прооксидантный индекс.

Результаты исследований и их обсуждение. Установлено, что реперфузия конечности вызывает длительный оксидативный стресс в тканях почки, о чем свидетельствует значительное накопление ТБК-активных продуктов ПОЛ в ее ткани. Вывлено однотипность в динамике изменений уровня ТБК-активных продуктов ПОЛ и активности каталазы между группами животных с реперфузионными изменениями и группой, где моделировали закрытую травму органов брюшной полости и гиповолемический шок.

В группе животных, где сочеталась реперфузия, травма органов брюшной полости и гиповолемический шок, развивалось истощение антиоксидантных механизмов, о чем свидетельствовала динамика показателя АПИ до седьмых суток, когда он на $37,8 \%$ был статистически меньше контрольных показателей $(\mathrm{p}<0,05)$. Это свидетельствует о высоком риске развития синдрома полиорганной недостаточности и необходимости дальнейшего изучения и разработки средств коррекции и профилактики.

Ключевые слова: ишемия; реперфузия; жгут; эксперимент; почка; перекисное окисление липидов 